\title{
Caring for the carer: quality of life and burden of female caregivers
}

\author{
Cuidando de quem cuida: qualidade de vida e sobrecarga de mulheres cuidadoras \\ Cuidando de quien cuida: calidad de vida y sobrecarga de mujeres cuidadoras
}

Michelly Guedes de Oliveira Araújo'

Michelinne Oliveira Machado Dutra'

ORCID: 0000-0003-4066-8964

Carla Carolina Silva Leite Freitas"

ORCID: 0000-0002-4780-7640

Tatiane Gomes Guedes "I'

ORCID: 0000-0001-7149-2290

Francisco Stélio de Souza"

ORCID: 0000-0002-9604-4133

Rosilene Santos Baptista"

ORCID: 0000-0001-7400-7967

'Universidade de Pernambuco. Recife, Pernambuco, Brasil.

"Universidade Estadual da Paraíba.

Campina Grande, Paraíba, Brasil

I'Universidade Federal de Pernambuco.

Recife, Pernambuco, Brasil.

How to cite this article:

Araújo MGO, Dutra MOM, Freitas CCDL, Guedes TG,

Souza FS, Baptista RS. Caring for the carer: quality of life and burden of female caregivers.

Rev Bras Enferm [Internet]. 2019;72(3):728-36.

doi: http://dx.doi.org/10.1590/0034-7167-2018-0334

Corresponding Author:

Michelly Guedes de Oliveira Araújo

E-mail: michelly.g@gmail.com

Submission: 05-22-2018 Approval: 02-18-2019

\begin{abstract}
Objective: To assess the quality of life and the burden of female caregivers. Method: Descriptive, cross-sectional, quantitative study carried out with 224 informal caregivers from March to July 2016. Three instruments were used: a characterization form for the caregiver, the WHOQOL-Bref questionnaire and the Zarit Burden Interview. The following tests were used: Cronbach's Alpha, Kolmogorov-Smirnov, Kruskal-Wallis, Spearman and Mann-Whitney. Results: The mean age of caregivers was 51.8 years with a standard deviation of 13.7. They were predominantly married, had a low income and low level of education, were first-degree relatives, had been providing care for one to five years and presented some pathology. The associations of quality of life that presented statistical significance were: income, marital status, number of people living with the caregiver and time of care. Conclusion: The burden was negatively correlated with QOL, that is, the greater the burden, the more impaired will be the life of these caregivers. Descriptors: Caregivers. Women's Health. Nursing. Family. Quality of Life.
\end{abstract}

\section{RESUMO}

Objetivo: Avaliar a qualidade de vida e sobrecarga de mulheres cuidadoras. Método: Estudo descritivo, transversal, quantitativo, realizado com 224 cuidadoras informais, de março a julho de 2016. Utilizaram-se três instrumentos: ficha de caracterização do cuidador, questionário WHOQOL-Bref e Escala de Zarit Burden Interview. Foram utilizados os testes: Alfa de Cronbach, Kolmogorov-Smirnov, Kruskal-Wallis, Spearman e Mann-Whitney. Resultados: As cuidadoras apresentaram média de idade de 51,8 anos e desvio-padrão de 13,7. Eram na maioria: casadas, baixa renda e pouca escolaridade, pertencentes ao primeiro grau de parentesco, exerciam o cuidado de um a cinco anos e apresentavam alguma patologia. As associações de qualidade de vida que apresentaram significância estatística foram entre: renda, estado civil, número de pessoas que vivem com a cuidadora e tempo de cuidado. Conclusão: A sobrecarga estabeleceu correlação negativa com QV, ou seja, quanto maior a sobrecarga, mais prejudicada será a vida dessas cuidadoras.

Descritores: Cuidadores. Saúde da mulher. Enfermagem. Família. Qualidade de vida.

\section{RESUMEN}

Objetivo: Evaluar la calidad de vida y sobrecarga de mujeres cuidadoras. Método: Estudio descriptivo, transversal, cuantitativo, realizado de marzo a julio de 2016 entre 224 cuidadoras informales. Se utilizaron tres instrumentos: ficha de caracterización del cuidador, cuestionario WHOQOL-Bref y Escala de Sobrecarga de Zarit; y las pruebas: Alfa de Cronbach, Kolmogorov-Smirnov, Kruskal-Wallis, Spearman y Mann-Whitney. Resultados: El promedio de edad de las cuidadoras era de 51,8 años con desviación típica de 13,7. La mayoría era casada, de escasos recursos y poca escolaridad, pertenecía al primer grado de parentesco, ejercía el cuidado entre uno y cinco años y presentaba alguna patología. Las asociaciones de calidad de vida con significación estadística eran: ingresos, estado civil, número de personas viviendo con ella y tiempo de cuidado. Conclusión: La sobrecarga estableció una correlación negativa con QV, es decir, a mayor sobrecarga, más perjudicada se vuelve la vida de las cuidadoras.

Descriptores: Cuidadoras. Salud de la Mujer. Enfermería. Familia. Calidad de Vida. 


\section{INTRODUCTION}

Home care is a service that can open up new horizons, decongest hospitals, reduce costs, reduce infections, and give chronic patients the possibility of returning to their homes, a space for humanized care, where family members are no longer only companions, but collaborators in the care provided(1).

The caregiver, who may or may not be a family member, is a person who provides care to the patient or dependent in their daily needs and tasks, excluding techniques or procedures that are exclusive to professionals, especially nurses ${ }^{(2,3)}$.

According to the Brazilian Institute of Geography and Statistics (IBGE) - National Household Sample Survey (PNAD), the number of caregivers reached 44.9 million in 2016, while in 2009 it was 1,203,005. The home care model has been a widely promoted alternative. This type of assistance has as priorities: the individual, the family context of the individual, the caregiver and the multi-professional team, who is able to act on the social determinants that influence the individual's health care ${ }^{(4,5)}$.

In the context of home care, most caregivers are informal. The work is usually assumed by a family member, who becomes the caregiver and, consequently, take on the responsibility of providing care $^{(6)}$. Brazilian studies emphasize that adult females represent the majority of caregivers ${ }^{(7)}$.

The excessive duties imposed on woman can seriously overload this potential caregiver, since, in addition to daily household activities, the woman also has to provide full time care. This care has its positive aspects, such as the feeling of accomplishing a duty and the self-satisfaction, and negative aspects, mainly arising from the burden ${ }^{(8)}$, which can affect the Quality of Life (QOL) of this caregiver.

The World Health Organization (WHO) defines QOL as "an individual's perception of their position in life in the context of the culture and value systems in which they live and in relation to their goals, expectations, standards and concerns"(9).

Caregiver burden is defined as the perception of caregivers about their physical and mental health, associated with their feelings, their psychological state of mind, their relevance as individuals and their social life, which can be a consequence of the care provided to the family member ${ }^{(10)}$.This accumulation of activities generates stress and affects several aspects of personal life, compromising the QOL of the caregiver.

\section{OBJECTIVE}

To assess the QOL and the burden of female caregivers.

\section{METHODS}

\section{Ethical aspects}

The study was approved by the Research Ethics Committee of the State University of Paraíba. The Informed Consent Form (ICF) was signed, as recommended in Resolution 466/12 of the National Health Council ${ }^{(1)}$.

\section{Design, setting and period}

This is a descriptive, cross-sectional and quantitative study. The study was carried out in the homes of the informal caregivers enrolled in the Family Health Strategy (FHS) of the city of Campina Grande/PB, from March to July 2016.

\section{Population and sample: inclusion and exclusion criteria}

The population was composed of all female informal caregivers of people with impaired mobility in the city of Campina Grande/ PB, which totaled 534 women. The sample was obtained through contact with nurses and Community Health Workers (CHWs) of all FHSs in the city. The finite population sampling resulted in a sample of 224 women. They met the inclusion criteria: being a caregiver for at least six months and being over 18 years old. Exclusion criteria were having difficulty communicating and being registered in a rural FHS.

\section{Study protocol}

The collection instruments were applied in home meetings. Three instruments were used to collect the data: a characterization form for the caregiver; WHOQOL-BREF; and the Zarit Scale, which assesses the caregiver burden.

The characterization form, elaborated by the author, included socio-demographic characteristics (age, civil status, education, socioeconomic level, number of people living in the same household, degree of kinship with the person cared for, time of care) and behavioral characteristics (life habits, leisure time, physical activity and nutrition).

The WHOQOL-BREF, which comprises 24 facets of QOL that make up the domains, offers a global indicator of overall QOL. It is divided in four domains of QOL: physical health, psychological, social relationships and environment ${ }^{(11)}$. In this study, the Portuguese version of the WHOQOL-BREF was used, which is the abbreviated version of WHOQOL-100 (12).

Answers were provided on a 5-point Likert scale. The domain scores were calculated by summing the mean scores of the questions that make up each domain. Then, these scores were converted to a scale of 0 to 100 . Scores closer to 100 indicate higher levels of satisfaction ${ }^{(13) .}$

The Zarit Burden Interview is composed of twenty-two items that assess the perceived impact of the act of caring on emotional and physical health, social life and financial situation. The cut-off points used were: 0 to 20 points correspond to little or no burden; 21 to 40 mild to moderate burden; 41 to 60 , moderate to severe burden; and from 61 to 88 , severe burden ${ }^{(14)}$.

\section{Analysis of results and statistics}

The data collected were stored in a database and analyzed in the Statistical Software - SPSS version 20.0. The confidence interval was $95 \%$.

In the descriptive analysis of the variables, absolute and relative frequency distributions were used. Cronbach's alpha coefficient was applied to confirm the internal consistency of the WHOQOLBREF and the Zarit Burden Interview. The Kolmogorov-Smirnov test evaluated the normal distribution of variables and found that they do not follow this distribution. Therefore, the associations between the domains of QOL and the characterization variables of the caregiver were analyzed using the Kruskal-Wallis test when they presented three groups or more, and the Mann-Whitney test 
when they presented two groups. The Spearman test was used to evaluate the correlation between the sum of all WHOQOL-BREF questions and the total score of the burden.

\section{RESULTS}

Among the 224 subjects who composed the sample, the age ranged from 18 to 86 years, with a mean of 51.8 years and a standard deviation of 13.7. Regarding marital status, $61.6 \%$ were married, $20.1 \%$ were single, $9.4 \%$ were widowed, and $8.9 \%$ were divorced. Regarding education, $48.2 \%$ did not complete elementary education, $10.3 \%$ had no schooling, and $4.9 \%$ had completed higher education. Regarding income, the majority (46\%) earned between one and two minimum wages and a minority (5.3\%) earned more than three wages.

Regarding the kinship of caregivers, $57.1 \%$ were first-degree relatives (father, mother or children), $23.7 \%$ were non-consanguineous - parent-in-law, daughter-in-law, son-in-law and wife/ husband and the others were second and third-degree relatives. The age range of 31-50 years was more representative at all degrees of kinship.

Regarding the number of people living with the caregiver, the most expressive number was three to five people, which appeared in $54 \%$ of the participants. In addition to the caregiver function, $84.4 \%$ of the participants were also responsible for domestic chores, $0.9 \%$ had a paid job and $14.7 \%$ performed care activities, domestic chores and had a paid job.

Regarding time of care, the period of one to five years predominated, representing $35.3 \%$ of the participants. The categories "from 1 to 5 years", "from 5 to 10 years" and "from 10 to 20 years" were more represented in the age group of 31-50. On the other hand, the younger age group (18-30) were mostly providing care for up to one year.

The WHOQUOL-BREF reliability was evaluated by Cronbach's Alpha and obtained a value of 0.77 , which indicates a good internal consistency.

Table 1 - Mean, median, standard-deviation, minimum and maximum quality of life scores of caregivers - Campina Grande - PB - 2016 (N=224)

\begin{tabular}{lccccc}
\hline \multicolumn{1}{c}{ Domains } & Mean & Median & Standard-deviation & Minimum & Maximum \\
\hline Physical health & 64.88 & 66.10 & 16.31 & 10.70 & 96.40 \\
Psychological & 59.22 & 62.50 & 16.96 & 4.20 & 95.80 \\
Social & 65.73 & 66.70 & 18.16 & 13.30 & 100.00 \\
Environmental & 51.60 & 51.55 & 13.30 & 21.50 & 93.80 \\
Quality of life (OQOLI)* $^{*}$ & 60.36 & 60.90 & 12.37 & 95.60 \\
\hline
\end{tabular}

*Overall Quality of Life Index.

Table 2 - Mean score of the facets of each domain from the domínio do Whoqol-Bref - Campina Grande - PB - 2016 (N=224)

\begin{tabular}{|c|c|c|}
\hline Domains & Facets & Mean score \\
\hline \multirow[t]{7}{*}{ Physical } & Q3. Pain and discomfort & 30.07 \\
\hline & Q4. Energy and fatigue & 45.74 \\
\hline & Q10. Sleep and rest & 60.38 \\
\hline & Q15. Mobility & 74.00 \\
\hline & Q16. Activities of daily living & 58.48 \\
\hline & Q17. Dependence on medicinal substances and medical aids & 68.86 \\
\hline & Q18. Work capacity & 67.41 \\
\hline \multirow[t]{6}{*}{ Psychological } & Q5. Positive feelings & 33.18 \\
\hline & Q6. Thinking, learning, memory and concentration & 67.86 \\
\hline & Q7. Self-esteem & 62.05 \\
\hline & Q11. Bodily image and appearance & 63.95 \\
\hline & Q19. Negative feelings & 69.64 \\
\hline & Q26. Spirituality, religion and personal beliefs & 41.07 \\
\hline \multirow[t]{3}{*}{ Social relationships } & Q20. Personal relationships & 69.86 \\
\hline & Q21. Social support & 63.23 \\
\hline & Q22. Sexual activity & 64.51 \\
\hline \multirow[t]{8}{*}{ Environmental } & Q8. Freedom, physical safety and security & 62.50 \\
\hline & Q9. Home environment & 58.71 \\
\hline & Q12. Financial resources & 37.50 \\
\hline & Q13. Health and social care: accessibility and quality & 49.67 \\
\hline & Q14. Opportunities for acquiring new information and skills & 25.78 \\
\hline & Q23. Participation in and opportunities for recreation/leisure activities & 67.30 \\
\hline & Q24. Physical environment (pollution/noise/traffic/climate) & 51.12 \\
\hline & Q25. Transport & 60.16 \\
\hline
\end{tabular}


Table 3 - Mean of the quality of life domains according to the age group of the caregivers - Campina Grande - PB - 2016 (N=224)

\begin{tabular}{|c|c|c|c|c|c|}
\hline \multirow{2}{*}{ Domains } & \multicolumn{4}{|c|}{ Age group (years) } & \multirow{2}{*}{$P$ value } \\
\hline & $18-30$ & $31-50$ & $51-60$ & Over 60 & \\
\hline Physical health & 65.87 & 66.02 & 60.78 & 66.92 & 0.179 \\
\hline Psychological & 67.13 & 62.36 & 53.32 & 58.87 & $0.002^{*}$ \\
\hline Social relationships & 63.89 & 67.45 & 63.42 & 65.57 & 0.539 \\
\hline Environmental & 42.71 & 53.13 & 48.11 & 53.90 & $0.012^{*}$ \\
\hline Quality of life (OQOLI) & 59.89 & 62.24 & 56.40 & 61.33 & $0.028^{*}$ \\
\hline
\end{tabular}

Kruskal Wallis test. *Significant

Table 4 - Means of the quality of life domains according to the number of people living with the caregivers - Campina Grande - PB - 2016 (N =224).

\begin{tabular}{lcccc}
\hline Domains & \multicolumn{3}{c}{ Number of people living with the caregiver } & 6 ou mais \\
\hline Physical health & $\mathbf{1 ~ a ~ 2 ~}$ & $\mathbf{3}$ a 5 & 64.93 & P value \\
Psychological & 63.63 & 65.59 & 58.08 & 0.457 \\
Social relationships & 58.81 & 59.77 & 72.73 & 0.791 \\
Environment & 65.83 & 63.77 & 54.56 & $0.048^{*}$ \\
Quality of lige (OQOLI) & 49.61 & 51.95 & 62.57 & 0.252 \\
\hline
\end{tabular}

Kruskal Wallis test. *Significant

In the OQOLI responses, the majority evaluated their life as "neither bad nor good" (44.6\%) and "good" (39.3\%). Likewise, in the question about their satisfaction with their health, $32.1 \%$ answered "neither satisfied nor satisfied" and $41.1 \%$ were "satisfied".

Table 3 presents the means of the quality of life domains according to the age group of caregivers.

There is an association between income and QOL domains, with statistical significance in the physical domain. However, caregivers who were in the category of more than three wages presented the worst scores. Therefore, a greater purchasing power is not necessarily associated with better QOL. The data showed no statistical significance in the association between the QOL domains and the activity performed by caregivers.

The association between the domains and the civil status showed a statistically significant difference in the social relationships'domain, since the separated/divorced individuals presented a mean score higher than the others. There was also a correlation between the QOL domains and the number of people living with the caregivers. There was a statistically significant relationship in the social domain, with the highest scores among those who live with six or more people (Table 4).

The association between the QOL domains and diseases showed no statistical significance. However, caregivers who do not have any disease presented a higher score in OQOLI than the others. The association between the QOL domains and kinship showed no statistically significant difference. However, the caregivers who were not consanguineous kins, but affinal kins - parent-in-law, sonin-law, daughter-in-law, step-father, step-mother, step-child and sibling-in-law - presented higher scores in the physical domain.

The comparison between the QOL scores and physical activity did not show significant statistical difference, and only the environmental domain had higher scores among those that practice some type of activity.

The association between the QOL domains and the time that these women had been providing care showed a statistically significant difference in the psychological domain. Thus, the caregivers who had performed this role for more than 20 years presented worst scores, a situation that also appeared in the OQOLI scores.

Regarding the distribution of caregivers in the different levels of burden, the lowest value was 5 and the maximum was 66 , with a mean of 28. Most caregivers (46.4\%) had moderate burden and $64.3 \%$ had a significant level of burden.

The reliability of the Zarit Interview was assessed using the Cronbach's alpha and a value of 0.79 was obtained, representing good internal consistency. The results of this scale are presented below.

More than half of the interviewees (53.6\%) answered that they never felt that the person receiving their care asked for more help than they needed. The question asking the caregivers if they felt that they didn't have enough time for themselves due to the time spent with the person cared for received three different answers: $43.3 \%$ never felt that, $24.1 \%$ felt it sometimes and $22.8 \%$ always feel it.

In the question about feeling stressed between caring and trying to meet other responsibilities, $63 \%$ answered sometimes, $36.6 \%$ answered quite frequently and $20.1 \%$ nearly always. A representative portion chose the option never for the following issues: feeling embarrassed over the person's behavior (88.4\%), feeling angry when around the person cared for (83\%), feeling that their relationships are affected in a negative way by the person cared for $(82.1 \%)$, feeling strained around the person cared for $(84.4 \%)$ and feeling uncomfortable about having people over (82.1\%).

Regarding the caregiver's concern with the future of the person cared for, the answers in both extremes obtained close percentages (34.4\% never and 33\% always). Regarding the dependence of the person cared for, $77.7 \%$ of caregivers claimed they always feel that the individual is dependent on them. In addition, $55.8 \%$ of caregivers reported they always feel that the person cared for sees them as the only one they could depend on. 
Table 5 - Mean of the overall quality of life index according to the different levels of burden - Campina Grande - PB - 2016 (N =224)

\begin{tabular}{|c|c|c|c|c|c|}
\hline & \multicolumn{4}{|c|}{ Levels of burden } & \multirow{2}{*}{$P$ value } \\
\hline & Little or no burden & Mild to moderate & Moderate to Severe & Severe & \\
\hline Overall Quality of Life Score & 89.71 & 82.87 & 79.72 & 84.50 & $0.000^{*}$ \\
\hline
\end{tabular}

Kruskal Wallis Test. * Significant

The data obtained through the Zarit Interview showed that most caregivers (66.5\%) do not think that their health was affected. The two next questions presented similar answers: $61.6 \%$ do not feel that they don't have as much privacy as they would like and $64.3 \%$ do not feel that their social life has suffered because they are caring for someone. An expressive number of caregivers (82.1\%) claimed they have no problems receiving visitors because of the presence of the person cared for. Regarding the financial situation, only $28.1 \%$ answered that they have enough money to take care of the person in addition to the rest of their expenses.

When asked if they feel they will be unable to take care of the person much longer, $65.6 \%$ of the caregivers answered they never felt like this; $11.6 \%$ answered that they have lost control of their life since the person's illness, while $75.4 \%$ never thought of that. It was found that $80.8 \%$ of the caregivers never thought about leaving the care to someone else. Among the participants, $66.5 \%$ answered that they never felt uncertain about what to do for the person cared for. In the questions about the possibility of doing more or doing a better job in caring, 38.4\% answered they have never thought of that, and $41.5 \%$ believed that this care could never be better.

It the last question, which addresses their overall burden, $32.6 \%$ answered that they do not feel burdened; $26.3 \%$, feel moderately burdened; $18.3 \%$ feel a little burdened; and the last two are equivalent, with $11.6 \%$ feeling highly burdened and $11.2 \%$ extremely burdened.

In Table 5, when the total sum of the WHOQOL-BREF score was compared with the levels of burden, a statistical significant relationship was found, showing that the higher the QOL score, the lower the burden.

No significant statistical difference was found between the QOL domains and the levels of burden. However, a moderate negative correlation (-0.383) was identified between the sum of the QOL scores and the burden questions. Then, one can interpret that the higher the QOL score, the smaller the burden, or vice versa.

\section{DISCUSSION}

The age variation of the participants is similar to national and international studies ${ }^{(15-17)}$. The prevalence of the age group of 3150 years, followed by those over 60 years, is corroborated by data from other researches ${ }^{(18-22)}$ and provides an interesting reflection - older adults are strongly represented among caregivers. This is also related to the fact that the caregiver role is primarily taken by the spouse. Other studies, carried out with caregivers from Spain, Poland and Denmark, also corroborate the predominance of married or partnered caregivers ${ }^{(15,16,18,23)}$.

The population studied presented a low level of education, considering that $58.5 \%$ have less than ten years of formal education.
Similar data are presented in a study carried out in Portugal, which found that only $7.1 \%$ of the caregivers had completed higher education ${ }^{(18)}$. Brazil also has a similar reality, as shown in a study with dependent older adults caregivers in the state of Bahia ${ }^{(17)}$.

The context of the activities performed beyond the caregiver role is related to the dynamics of caregiving, which may induce caregivers to reduce their working time or even to give it up, according to the patient's dependence ${ }^{(24)}$.

The analysis of the degree of kinship showed that first-degree consanguineous relatives (mothers and daughters) were the main responsible for care, followed by those who were not consanguineous, represented by daughters-in-law, mothers-in-law and wives. It was also observed that the age group of 31 to 50 years was predominant in all degrees of kinship. These findings were similar to those of studies with relative caregivers of elderly dependents and caregivers of people with chronic diseases ${ }^{(17,25)}$, which also found this age group as the most representative and found that the patient's children were the predominant caregivers, followed by the spouse ${ }^{(15,18,26)}$.

Regarding diseases, $58.5 \%$ of the caregivers reported having some pathology, especially hypertension, followed by diabetes. A study with caregivers of children and adolescents in the CAPSi in the state of Rio Grande do Sul obtained a similar percentage of caregivers who had a disease ${ }^{(27)}$. More than four-fifths of caregivers reported having at least one chronic illness, and nearly two-thirds had several. A study conducted in the southern US with informal caregivers of people with dementia corroborates these data, with hypertension, arthritis, and heart disease as the predominant conditions ${ }^{(28)}$.

In this study, we found a mean of 60.36 points in the OQOLI of caregivers of people with impaired physical mobility, which was very close to the international study that evaluated the QOL (60.82) of caregivers of patients with cerebrovascular accident ${ }^{(16)}$. However, it is lower than the value found in another national study with the same population, in which the score obtained (62.00) was associated with many factors, such as a long time of care, the limitations of the patients with CVA and their dependence in daily activities ${ }^{(29)}$.

A study carried out in Colombia with caregivers of patients with chronic diseases found that, if you include caregivers of people with several different diseases, even if the samples are representative, some will require more physical and emotional commitment than others $^{(25)}$. This fact can affect the QOL of these caregivers.

The minimum score found was in the environment domain (51.60), followed by the psychological domain (59.22); the maximum was in the social relationships domain (65.73) followed by the physical health domain (64.88). The data is in accordance with a study carried out in the Triângulo Mineiro, which found equivalent scores for all the domains. When comparing the mean scores of the caregivers with the reference group (non-caregivers), this 
study found higher scores in all domains ${ }^{(30)}$. Thus, the occurrence of a stroke damages both the affected individual and the caregiver. Another study carried out with family members caregivers revealed higher scores in the physical health domain (66.72) and in social relationships (60.86), and lower scores in the environment domain (52.51) which is also similar to the results of the present study ${ }^{(31)}$.

A national study that assessed the $\mathrm{QOL}$ of caregivers of older adults found a mean of 55.6 in the OQOLI, lower than that reached in this study. However, the domains that presented the highest scores were physical health (54.8) and psychological (54.8), while the lowest were social relationships (54.8) and environment (41.4) (17). Thus, QOL presented a median level, which may be justified by the patient's impaired health status and the limitations to the caregiver's social life.

There was no statistical significance in the association between the domains and the activities performed by the caregivers, but smaller scores were found in all domains, except the physical health domain, for women who also did domestic work and worked outside. Even so, it is possible to verify that the QOL of these subjects will be impaired, because besides taking care of a person with limitations, they still have to manage domestic and work tasks.

The association between marital status and the QOL domains showed statistical significance in the social domain, with the highest score in the separated/divorced category. This result shows that, when establishing a relationship, an additional concern will be part of the woman's life - to balance the difficulties arising from being a caregiver while finding ways so that the caregiver routine does not affect the relationship. Contrary data were found in another study, in which the married or partnered caregivers obtained a mean of more than 10 points in the OQOLI ${ }^{(31)}$.

The association between the number of people living in the same household and the domains showed statistical significance in the social relationships' domain. The category of "six or more people" in the same residence had the highest value, which may be due to the help given by these other individuals. This facilitates the strenuous care routine, since alternating and distributing tasks can reduce the burden of each one, which can improve the QOL.

A study carried out in São Paulo found that caregivers with a disease have a lower mean in the OQOLI when compared to those who do not report diseases ${ }^{(31)}$. In this study, this association was not statistically significant, but the OQOLI was lower among caregivers with some pathology. This aspect deserves to be highlighted, because, with all the obligations of these caregivers, their self-care becomes deficient and is forgotten. With the presence of a disease, this situation tends to get worse, because it can affect the caregiver's life and the quality of the care provided.

In the environmental domain, the facet related to the opportunity to acquire information had the third worst score, demonstrating how much the knowledge needed its distant from its access. Another study found similar data, as $67 \%$ of the respondents mentioned the importance of having an interest in learning more about the family member's illness, which requires that the caregiver is able to gain information through interactions with family members, caregivers and health professionals ${ }^{(32)}$. A complicating factor in this scenario is the low level of education of the population studies, which makes it difficult to find and assimilate knowledge about the disease and adequate care practices.
In the social relationships domain, it was found that caregivers expect other family members or close friends to volunteer to help. However, this does not happen very often, resulting in a lack of support. A study that addressed care-related conflicts identified that caregivers reported needing more support. However, only $20 \%$ acknowledged the importance of asking for help, while others did not see this as an important attitude ${ }^{(32)}$.

This research found a statistically significant relationship between the psychological domain and the time of care, with a higher value among women who have been providing care for more than 20 years. This demonstrates that the longer the time care, the more impaired is the QOL. The 'spirituality' facet had the second lowest value in this domain. This hinders the caregiver's spirituality and the possibility of keeping good expectations, which would improve the understanding of the health-disease process and the development of coping strategies, consequently improving $\mathrm{QOL}^{(33)}$.

'Positive feelings' was the facet with the lowest value in the psychological domain. This might be due to the many difficulties faced daily, which result in disappointment, hopelessness and desperation and make it difficult to keep optimistic feelings. However, even if it appears exhausting, caring for someone also provides gratifying sensations, such as inner comfort and a feeling of duty accomplished, rising above all adversities ${ }^{(17)}$.

Thus, negative feelings surround caregivers at several points of their trajectory. Another study observed that the feeling of loneliness was habitual among caregivers, similar to the experience of mourning, because these caregivers were detached from the world they lived and lost their sense of life. This experience, which also causes discontent and sadness, is associated with the lack of recognition for their work and dedication. Along the way, this feeling arises, as both the dependent and the family do not seem grateful for all the efforts made in the act of caring. On the other hand, receiving the least gesture of admiration, gratitude and even words of encouragement can have a significant impact ${ }^{(34)}$, providing a sense of reward for their voluntary effort as caregivers.

An important observation was that caregivers opted for negative alternatives fearing judgment and, especially, judging themselves. Options that showed more burden were interpreted as lamentation and protest, and the caregivers did not want to give that impression because they felt guilty. Therefore, they did not report feeling overburdened with care. However, the little time reserved for leisure, personal relationships and self-care contradicts these claims. This way, they do not realize or express the real burden generated by care ${ }^{(35)}$.

Another aspect that influenced the answers of the Zarit Interview was the degree of kinship and the affection in the caregiver-patient relationship. Depending on the ties, even if the answers could be the most unfavorable, the relationship stands out, resulting in the variety of answers found ${ }^{(20)}$.

The degree of dependence of the person cared for and the perception of the caregiver on the abilities of this subject is associated with the burden, since, in the attempt to help and due to a lack of education and fear of being neglectful, the caregiver performs all the activities and does not give space for the patient to develop ${ }^{(20)}$.

An expressive aspect in this study was dependence, since more than $95 \%$ of caregivers claimed, at different intensities, that they felt that the patient depended on them, and $77.7 \%$ stated that 
they always felt like this. Therefore, a common concern is that the person cared for may not accept their limitations and the loss of autonomy, which generates conflicts due the role reversal, being another factor adding to the burden ${ }^{(34)}$.

Even without a significant correlation between the burden and the QOL domains, the sum of the QOL questions and the burden were correlated. This indicates that the higher the burden, the lower the QOL of the caregiver ${ }^{(17,29)}$. The association between burden and socio-demographic variables did not show statistical significance.

\section{Limitations of the study}

The limitations are related to the impossibility of comparing QOL with the burden of these caregivers before assuming this function, during the care and after undergoing some type of intervention. The visualization and analysis of these three periods would allow us to understand the main aspects that contribute positively and negatively throughout the process.

\section{Contributions to the area of nursing, health or public policy}

This study may foster the development of new research in the area, broaden the horizons of the topic and promote public policies aimed at this public. Public attention should be directed at caregivers, with more training for the health team, appropriate means and structures to carry out actions aimed at these subjects, effective interventions to modify this reality and discussions on the subject. Nursing professionals can have an effective contribution, since the implementation of health promotion measures can improve the lives of these individuals.

\section{CONCLUSION/FINAL CONSIDERATIONS}

The results showed that the caregivers of people with impaired physical mobility are predominantly married, have a low level of education and low purchasing power, are mostly first-degree relatives and, in addition to caring, also perform domestic activities. The minority engaged in physical activity, and the most mentioned disease was hypertension.

QOL presented a correlation with some socio-demographic variables. Factors such as income, number of people living in the household and time of care, for example, exert a significant influence over the QOL of these caregivers. The burden, which was classified as moderate, was negatively correlated with the $\mathrm{QOL}$, that is, the higher the burden, the more impaired will be the life of these caregivers.

Thus, the role of caregiver requires a range of physical skills and psychological preparation to deal with routine activities and adversities. So, maintaining a good QOL and reducing the burden are challenges for this caregiver and for the health team, specifically for nursing professions.

\section{PROMOTION/ACKNOWLEDGMENT}

This study received financial support from the Coordination for the Improvement of Higher Education Personnel (CAPES).

\section{REFERENCES}

1. Ministério da Saúde (BR), Secretaria de Atenção à Saúde, Departamento de Atenção Básica. Caderno de atenção domiciliar [Internet]. Vol. 2. Brasília (DF): Ministério da Saúde; 2012 [cited 2019 Mar 24]. 204 p. Available from: http://bvsms.saude.gov.br/bvs/publicacoes/caderno_ atencao_domiciliar_melhor_casa.pdf

2. Ministério da Saúde (BR), Agência Nacional de Vigilância Sanitária (ANVISA). Resolução RDC № 11, de 26 de janeiro de 2006. Dispõe sobre o Regulamento Técnico de Funcionamento de Serviços que prestam Atenção Domiciliar [Internet]. Diário Oficial da União: República Federativa do Brasil; 2006 [cited 2019 Mar 24]. Jan 26. [about 5 screens]. Available from: http://bvsms.saude.gov.br/bvs/saudelegis/ anvisa/2006/res0011_26_01_2006.html

3. Ministério da Saúde (BR), Secretaria de Atenção à Saúde, Secretaria de Gestão do Trabalho e da Educação na Saúde. Guia prático do cuidador [Internet]. Brasília (DF): Ministério da Saúde; 2008 [cited 2019 Mar 24]. 64 p. Available from: http://bvsms.saude.gov.br/bvs/ publicacoes/guia_pratico_cuidador.pdf

4. IBGE: Instituto Brasileiro de Geografia e Estatística [Internet]. Rio de Janeiro: IBGE; 2009. Pesquisa Nacional por Amostra de Domicílio 2009 [cited 2019 Mar 24]; [about 1 screen]. Available from: http://www.ibge.gov.br/home/estatistica/populacao/trabalhoerendimento/pnad2009/.

5. IBGE: Instituto Brasileiro de Geografia e Estatística [Internet]. Rio de Janeiro: IBGE; 2016. Plano Trabular - PNAD 2016 Cuidado de pessoas. Rio de Janeiro [cited 2019 Mar 24]; [about 1 screen]. Available from: https://agenciadenoticias.ibge.gov.br/agencia-detalhe-de-midia.html?v iew $=$ mediaibge\&catid=2103\&id $=1601$.

6. Rocha MPF, Vieira MA, Sena RR. [Unveiling the routine of informal caregivers for the elderly]. Rev Bras Enferm [Internet]. 2008 [cited 2019 Mar 25];61(6):801-8. Available from: http://dx.doi.org/10.1590/S0034-71672008000600002 Portuguese.

7. Gratão ACM, Vendrúscolo TRP, Talmelli LFS, Figueiredo LC, Santos JLS, Rodrigues RAP. Burden and the emotional distress in caregivers of elderly individuals. Text Context Nursing [Internet]. 2012 [cited 2019 Mar 25];21(2):304-12. Available from: http://dx.doi.org/10.1590/ S0104-07072012000200007

8. Nardi EFR, Sawada NO, Santos JLF. The association between the funtional incapacity of the older adult the family cargiver's burden. Rev Lat Am Enfermagem [Internet]. 2013 [cited 2019 Mar 25];21(5):1096-103. Available from: http://dx.doi.org/10.1590/S0104-11692013000500012

9. WHOQOL GROUP. The world health organization quality of life assessment (WHOQOL): position paper from the world health organization. Social Science Medicine [Internet]. 1995 [cited 2019 Mar 25]; 41(10):1403-9. Available from: https://doi.org/10.1016/0277-9536(95)00112-K 
10. Zarit SH, Reever KE, Bach-Peterson J. Relatives of impaired elderly: correlates of feeling of burden. Gerontologist [Internet]. 1980 [cited 2019 Mar 25];20(6):649-55. Available from: https://doi.org/10.1093/geront/20.6.649

11. Fleck MPA, Louzada S, Xavier M, Chachamovich E, Vieira G, Santos L et al. [Application of the Portuguese version of the abbreviated instrument of quality life WHOQOL-bref]. Rev Saúde Pública [Internet]. 2000 [cited 2019 Mar 25];34(2):178-83. Available from: http://dx.doi. org/10.1590/S0034-89102000000200012 Portuguese.

12. WHOQOL Group. Programme on Mental Health. Division of mental health and prevention of substance abuse. World Health Organization. WHOQOL: measuring quality of life. Geneva:WHO [Internet]; 1997 [cited 2019 Mar 25]. Available from: http://apps.who.int/iris/ bitstream/10665/63482/1/WHO_MSA_MNH_PSF_97.4.pdf

13. Dias DSG, Carvalho CS, Araujo CV. [Comparison of subjective perceptions of quality of life and well-being of elderly people living alone, with family and institutionalized]. Rev Bras Geriatr Gerontol [Internet]. 2013 [cited 2019 Mar 25];16(1):127-38. Available from: http://dx.doi. org/10.1590/S1809-98232013000100013 Portuguese.

14. Zarit SH, Zarit JM. The memory and behavior problems checklist - 1987R and the burden interview (Technical report). Pennsylvania: Pennsylvania State University; 1987.

15. Rodrigues JEG, Machado ALG, Vieira NFC, Fernandes AFC, Rebouças CBA. [Quality of life and work overload in family caregivers of elderly dependants]. Cienc Enferm [Internet]. 2014 [cited 2019 Mar 25];20(3): 119-29. Available from: http://www.redalyc.org/ pdf/3704/370441817011.pdf Portuguese.

16. Silva IFG, Neves CFS, Vilela ACG, Bastos LMD, Henriques MILS. [Living and Caring After a Stroke]. Rev Enf Ref [Internet]. 2016 [cited 2019 Mar 25];4(8):103-11. Available from: http://dx.doi.org/10.12707/RIV15047 Portuguese.

17. Anjos KF, Boery RNSO, Pereira R. Quality of life of relative caregivers of elderly dependents at home. Text Context Nursing [Internet]. 2014 [cited 2019 Mar 25];23(3):600-8. Available from: http://dx.doi.org/10.1590/0104-07072014002230013

18. Sequeira C. Difficulties, coping strategies, satisfaction and burden in informal Portuguese caregivers. J Clin Nurs [Internet]. 2013 [cited 2019 Mar 25];22(3-4):491-500. Available from: http://doi.org10.1111/jocn.12108

19. Coura AS, Nogueira CA, Alves FP, Aragão JS, França IFX, Medeiros KKAS. Quality of life of caregivers of octogenarians: a study using the WHOQOL-BREF. Invest Educ Enferm [Internet]. 2015 [cited 2019 Mar 25];33(3):529-38. Available from: http://doi.org/10.17533/udea.iee. v33n3a17

20. Pereira RA, Santos EB, Fhon Jr S, Marques S, Rodrigues RAP. Burden on caregivers of elderly victims of cerebrovascular accident. Rev Esc Enferm USP [Internet]. 2013 [cited 2019 Mar 25];47(1):182-8. Available from: http://dx.doi.org/10.1590/S0080-62342013000100023

21. Gonçalves LHT, Costa MAM, Martins MM, Nassar SM, Zunino R. The family dynamics of elder elderly in the context of Porto, Portugal. Rev Lat Am Enfermagem [Internet]. 2011 [cited 2019 Mar 25];19(3):458-66. Available from: http://dx.doi.org/10.1590/S0104-11692011000300003

22. Oliveira DC, Carvalho, GSF, Stella F, Higa CMH, D'elboux MJ. [Quality of life and work overload among elderly outpatient caregivers]. Texto Contexto Enferm [Internet]. 2011 [cited 2019 Mar 25];20(2):234-40. Available from: http://dx.doi.org/10.1590/S0104-07072011000200003 Portuguese.

23. Labra C, Millan-Calenti JC, Bujan A, Nunez-Naveira L, Jensen AM, Peersen MC et al. Predictors of caregiving satisfaction in informal caregivers of people with dementia. Arch Gerontol Geriatr [Internet]. 2015 [cited 2019 Mar 25];60(3):380-8. Available from: http://doi. org10.1016/j.archger.2015.03.002

24. Pimenta GMF, Costa MASMC, Gonçalves LHT, Alvarez AM. Profile of the caregiver of dependent elderly family members in a home environment in the city of Porto, Portugal. Rev Esc Enferm USP [Internet]. 2009 [cited 2019 Mar 25];43(3):606-11. Available from: http:// dx.doi.org/10.1590/S0080-62342009000300016

25. Toscano JHA, Mercado MV. [Quality of life of informal caregivers of chronically ill persons]. Aquichan [Internet]. 2014 [cited 2019 Mar 25];14(3):417-29. Available from: http://doi.org/10.5294/aqui.2014.14.3.11 Spanish.

26. Dallalana TM, Batista MGR. [Quality of life of caregivers during the hospitalization of the patient under care in an emergency unit: some associated factors]. Ciênc Saúde Colet [Internet]. 2014 [cited 2019 Mar 25];19(11):4587-94. Available from: http://doi.org10.1590/1413812320141911.16592013 Portuguese.

27. Farias CA, Lima POC, Ferreira LA, Cruzeiro ALS, Quevedo LA. [Work overload faced by caregivers assisting frequenters of a psychosocial care center for children and adolescents in the south of Brazil]. Ciênc Saúde Colet [Internet]. 2014 [cited 2019 Mar 25];19(12):4819-27. Available from: http://doi.org10.1590/1413-812320141912.19182013 Portuguese.

28. Wang XR, Robinson KM, Carter-Harris L. Prevalence of chronic illnesses and characteristics of chronically ill informal caregivers of persons with dementia. Age Ageing [Internet]. 2014 [cited 2019 Mar 25];43(1):137-41. Available from: http://doi.org/10.1093/ageing/aft142

29. Caro CC, Mendes PVB, Costa JD, Nock LJ, Cruz DMC. Independence and cognition post-stroke and its relationship to burden and quality of life of family caregivers. Top Stroke Rehabil [Internet]. 2017 [cited 2019 Mar 25];24(3):194-9. Available from: http://doi/org/10.1080/1074935 7.2016.1234224

30. de Lima ML, Santos JLF, Sawada NO, Lima LAP. Quality of life of individuals with stroke and their caregivers in a city of Triângulo Mineiro. Rev Bras Epidemiol [Internet]. 2014 [cited 2019 Mar 25];17(2):453-64. Available from: http://doi.org/10.1590/1809-4503201400020013enG

31. Amendola F, Oliveira MAC, Alvarenga MRM. Influence of social support on the quality of life of family caregivers while caring for people with dependence. Rev Esc Enferm USP [Internet]. 2011 [cited 2019 Mar 25];45(4):880-5. Available from: http://dx.doi.org/10.1590/ 


\section{S0080-62342011000400013}

32. Pinto FNFR, Barham EJ, Prette ZAPD. Interpersonal conflicts among family caregivers of the elderly: the importance of social skills. Paidéia [Internet]. 2016 [cited 2019 Mar 25];26(64):161-70. Available from: doi:10.1590/1982-43272664201605

33. Afanador NP. Bienestar espiritual de los cuidadores familiares de niños que viven enfermedad crónica. Inv Enf [Internet]. 2007 [cited 2019 Mar 25];9(1):20-35. Available from: http://www.redalyc.org/pdf/1452/145212858003.pdf

34. Pereira HR, Botelho MAR. Sudden informal caregivers: the lived experience of informal caregivers after an unexpected event. J Clin Nurs [Internet]. 2011 [cited 2019 Mar 25];20(17-18):2448-57. Available from: https://doi.org/10.1111/j.1365-2702.2010.03644.x

35. Puig M, Rodriguez N, Lluch-Canut MT, Moreno C, Roldan J, Monteso P. Quality of life and care burden among informal caregivers of elderly dependents in catalonia. Rev Port Enferm Saúde Mental [Internet]. 2015 [cited 2019 Mar 25];(14):9-14. Available from: http://dx.doi. org/10.19131/rpesm.0100 